УДК 342.34

DOI https://doi.org/10.32837/apdp.v0i85.1833

\title{
Я.М. Крегул
}

\section{ПУБЛІЧНИЙ КОНТРОЛЬ В УКРАЇНІ ТА ФРАНЦІї: ПОРІВНЯЛЬНО-ПРАВОВЕ ДОСЛІДЖЕННЯ}

Постановка проблеми. Питання забезпечення відповідності нормативно-правових актів життєвим реаліям в усі часи хвилювало як законодавця, так і громадянське суспільство. Першого - через необхідність досягнення державних цілей в сенсі регулятивного впливу на суспільні відносини, а других - внаслідок властивого кожному окремому індивіду та групі людей особистого мотиву до правового пошуку комфортного життя у суспільстві. Зокрема, йдеться про виявлення чинників, які або заважають бачити ідеї справедливості і формальної рівності в праві, або можуть сприяти перетворенню формальних юридичних конструкцій в ефективно функціонуючі основи суспільного устрою.

Серед численних факторів, як позитивних, так і негативних, які зумовлюють розвиток правової бази держави, доречно звернути особливу увагу на впровадження у процес нормотворення не лише органів виконавчої та законодавчої влади, які наділені правотворчими функціями за Конституцією держави, а і тих неформальних соціальних структур, які, можливо, не будуть відігравати визначальної ролі в цьому процесі, однак зможуть надати аргументи «за» або «проти» прийняття певних нормативно-правових актів.

Слід зауважити, що, починаючи вже з першої стадії прийняття будь-якого нормативно-правового акту, слід враховувати соціальні потреби і можливості суспільства й держави до реалізації таких нововведень у законодавчому полі, тобто, проаналізувати відповідну проблемну ситуацію та її вирішення в рамках юридичних форм, які мають характер загальнообов'язкових, передбачених для виконання, призводять до відповідальності за їх невиконання тощо.

Отже, механізм комунікації між державною владою, яка відповідальна за нормотворчий процес, зміну та відміну правових положень, в основі яких лежать соціальні фактори, та суспільством, що визначає їх якість, не може відбуватися в закритій системі. Державна влада вимагає контролю з боку громадськості, оскільки фактично саме остання надала їй повноваження для створення правового поля. Поняття взаєморозуміння між державною владою і суспільством закликає враховувати різні точки зору при діалектичному обміні думками. Такий діалектичний підхід повинен захистити нас від одностороннього аналізу і висновків [1, с. 21].

3 огляду на складні взаємні вимоги між державною владою і суспільством, тема контролю навряд чи зможе втратити свою актуальність у будь-якій державі незалежно від її розвитку. Хто і яким чином здійснює контроль? Кого і з якою метою контролюють у суспільстві? Зрештою, це визначає ступінь демократичності і деспотичності держави. 
Аналізуючипредставленнівмежахсучасних науковихпідходівконцепціїпублічного контролю, особливу увагу слід звернути на те, що в українській правовій теорії не вироблено єдиного розуміння змісту і поняття публічного контролю. Не створено законодавчої концепції способів реалізації публічного контролю над державною владою, не розглядаються проблеми взаємоконтролю влади і суспільства, зокрема, як порушення прав людини, так і порушення права влади на конфіденційність при певних обставинах, що витікають із забезпечення національних інтересів держави. Вказані аспекти аргументують необхідність і своєчасність наукового осмислення та розробки проблематики поняття «публічного контролю» в галузі науки «конституційне право». Саме тому тема статті є актуальною і науково перспективною.

Аналіз останніх досліджень і публікацій. Науково-теоретичне підгрунтя цього дослідження становлять праці таких відомих вітчизняних науковців, як А. Буханевич, С. Вітвіцький, Н. Дніпренко, В. Журавльова, С. Косінов, В. Кравчук, А. Лапшина, Г. Пришляк, О. Савченко, Є. Селіванова та інші.

Не оминули своєю увагою проблему публічного контролю і зарубіжні вчені. Зокрема, цікаві напрацювання з цього питання представлені у працях Л.Г. Лукойдес i М. де Сальвіа. Вони розглядають публічний контроль як основний елемент, який стосується прозорої діяльності судової системи. Так, Л.Г. Лукойдес вважає, що саме публічний контроль за діяльністю органів правосуддя є критерієм реалізації принципу гласності системи державного управління загалом [2, с. 8]. Подібну позицію відстоює і М. де. Сальвіа, зазначаючи, що «гласність судового процесу є однією із суттєвих гарантій його справедливості, вона захищає від негласного правосуддя i є одним із засобів збереження довіри до судових органів [3, с. 548-549]. Отже, обидва науковці наголошують на тому, що гласність забезпечує довіру суспільства до державних органів і є основою публічного контролю.

На мою думку, на увагу заслуговує також інтерпретація сутності публічного контролю, відображена французькими дослідниками. Так, В.К. Рахуа вважає, що публічний контроль у державному управлінні є «важливим критерієм безпосередньої реалізації принципу публічності, відповідно до якого запроваджуються регламентаційні механізми, які стимулюють громадян до участі у здійсненні контролю за діяльністю державної влади» [4, с. 187]. Відповідно до цього принципу, який має бути чітко закріпленим у національному законодавстві, виховується не тільки рівень правової свідомості громадян, а й їхня зацікавленість у безпосередній участі в формуванні демократичного суспільства шляхом нагляду за діями влади.

Такої ж думки французькі дослідники Р. Давид, К. Жооффре-Спинозі, які визнають, що публічний контроль є обов'язковою умовою для формування громадянського суспільства, а тому нагляд громадян за діями влади є запорукою їі ефективності та результативності. Тому, на думку Р. Давіда, К. Жоффре-Спинозі, в зміст поняття публічного контролю доцільно вкладати такі елементи та норми, які регулюють стосунки між людьми у сфері їх права на здійснення нагляду за діяльністю соціальних інститутів [5, с. 64].

Більш детально розкриває суть поняття публічного контролю італійський науковець Н. Ратічері, який вважає, що явище публічного контролю доцільно розглядати крізь реалізацію інструментів громадянського та громадського обов'язку 
щодо здійснення нагляду за діями інститутів державного управління. Науковець акцентує увагу на окресленні сутності критеріїв публічного контролю, які дають змогу чітко визначити його зміст.

Обравши такий дослідницький підхід, вдалося розробити критерії, які збільшують правові можливості громадян щодо їх впливу на владу та нагляду за їі діями. Аналізуючи природу публічного контролю, він відштовхується від розуміння його юридичного змісту, особливу увагу звертаючи на права та обов'язки сторін (громадян та органів державної влади). Найбільша методологічна цінність розуміння значимості публічного контролю, запропонованого Н. Ратічері, полягає в тому, що він розглядає участь громадян у сфері публічного контролю як таку, яка абсолютно залежить від волі та бажання самих громадян стосовно їх участі в державному управлінні [6, с. 34,41$]$.

Метою статті є обгрунтування необхідності «публічного контролю» як інституту, який охоплює взаємодію органів державної влади із суспільством на основі порівняльно-правового аналізу розуміння цього явища в Україні та Франції. Досягнення цієї мети дасть можливість розглянути поняття «публічного контролю», як категорії, яка виникла внаслідок модернізації доступу громадськості до діяльності державних інститутів, та допоможе знайти шляхи вдосконалення публічного контролю в Україні на основі здобутків зарубіжного досвіду.

Виклад основного матеріалу дослідження. Можна з упевненістю стверджувати, що найуніверсальнішим методом участі громадян в управлінні державними справами у всіх країнах із демократичними режимами є вибори. Так, народ, надаючи згоду на використання державною владою своїх повноважень, наділяє ї̈ правом законного примусу і погоджується з тим, що в подальшому парламент, президент і уряд діють самостійно без згоди громадян. Таким чином, фактично громадяни отримують законне право впливати на державні процеси і публічну владу єдиний раз - на виборах. На думку М.В. Цвіка, шляхом вільних виборів народ передає державі владу, що йому належить, а остання здійснює їі від імені і за участю народу [7, с. 137]. Однак, незважаючи на це, виборці не лише мають право, а навіть змушені контролювати своїх обранців з метою недопущення узурпації влади.

Про таку природу речей влучно висловився М. Дюверже: «Правління народу за допомогою народу», «керування нацією за допомогою її представників» - голосні слова, які нічого не означають. Ніхто і ніколи не бачив народ, який сам собою керує, і ніколи не побачить. Будь яке правління олігархічне, і це неминуче призводить до панування небагатьох осіб над масою [8, с. 244].

3 цього твердження вбачається, що воля народу не є дієвою і остаточною, оскільки в парламенті головує більшість, яка виступає як форма підтвердження права на здійснення правління у державі фактичною меншістю, яка дуже часто представляє олігархічні кола суспільства, перетворюючи народ із суб'єкта влади в її об'єкт. Що ж залишається народу? Укласти із владою угоду про принципи її роботи на користь суспільства з одного боку, а з другого боку - добровільно-примусове виконання законів, які забезпечують життєдіяльність суспільства і порядок у ньому.

Слушну думку щодо публічного контролю над державними інституціями висловив С.Ф. Денисюк. Він вважає, що в демократичних суспільствах народ як сукуп- 
ність громадян та їхніх асоціацій здійснює публічну владу безпосередньо і через систему інститутів. Інституції, яким народ делегує власні повноваження - органи державної влади та органи місцевого самоврядування, діють від його імені. Саме тому народ повинен контролювати як свою (самоконтроль, внутрішній контроль), так і їхню (контроль і зовнішній контроль) діяльність [9, с. 46].

3 наведеного вбачається, що публічний контроль тісно пов'язаний із державною владою. Так, у статті 12 французької Декларації прав людини і громадянина 1789 року (далі - Декларація) зазначено: «Для гарантії прав людини і громадянина необхідна державна сила; вона створюється в інтересах всіх, а не для особистої вигоди тих, кому вона довірена».

У цій статті Декларації зумовлений зміст існування державної влади як головної сили, якій надано право народом забезпечити дотримання основних прав громадян, відвернути насилля, особисту помсту та агресію між людьми. Фактично своїм правом вибору люди наділили певних громадян державною владою і дали свою згоду на виконання законів і норм, напрацьованих цією владою, але при цьому вони залишають за собою право вимагати звітності і виконання нею тих же законів і норм, які передбачені для всіх громадян.

Цю ідею влучно втілив у своєму вченні італійський науковець Р. Претто, який наголосив на тому, що публічний контроль розглядається у співвідношенні з проблемою громадського обов'язку, який має зводитися до забезпечення публічності діяльності відповідних гілок державної влади. Важливу роль публічний контроль відіграє у нагляді за діяльністю законодавчої влади, яка має гарантувати громадянам не лише справедливий розгляд справ у судах, а й відкритість і прозорість формування та реалізації законодавчих ініціатив. Одним словом, влада має бути постійно підзвітною перед своїми громадянами, в цьому і є сутність публічного контролю [10, с. 27]. 3 огляду на це твердження, публічний контроль є показником рівня довіри населення до державної влади, тобто все, що відбувається з ініціативи державної влади і здійснюється нею і її окремими представниками, має бути «прозорим», тому що контролювати можна тільки доступний для огляду і чіткий об'єкт, який піддається аналізу за змістом і формою.

Етимологія поняття «прозорість» або «транспарентність» (як терміну іноземного походження) бере свій початок від латинських “trans" - прозорий, наскрізь i "pareo" - бути очевидним. Англійське слово “transparent”перекладається як прозорий, зрозумілий, явний, з французької “transparent” - прозорий. Категорія транспарентності як ознака адміністративної та політичної комунікації між публічною владою та населенням була розроблена в англо-американській соціальній науці, де прозорість перед об’єктом державного управління визначалась поняттям “transparency”, а відкритість влади для участі в державному управлінні з боку членів суспільства - поняттям “ореnness” [11, с. 7].

Я погоджуюся з думкою англійського науковця К. Худа, який стверджує, що «транспарентність може означати, в широкому значенні, вимогу до уряду діяти відповідно до фіксованих та опублікованих норм, базуючись на інформації та процедурах, які доступні для громадськості, і в чітко окреслених галузях діяльності» $[12$, с. 5]. При цьому можна додати, що транспарентність - це будь-яка інфор- 
маційна політика демократичної держави, побудована на принципах відкритості та доступності для громадян, про діяльність органів публічної влади та її окремих представників.

У французькій юридичній науці цей термін існує під назвою «транспарентність» (від фp. la transparense - прозорість). Незважаючи на те, що цей термін у юридичний лексикон був введений французькими вченими не так давно, суть його була викладена ще в 1789 році у статті 15 славнозвісної Декларації: «Суспільство має вимагати від будь-якої посадової особи звіту про її діяльність» [13]. На законодавчому рівні у Франції це право закріплено Законом № 78-753 від 17 липня 1978 року «Про заходи, спрямовані на покращення відносин між органами управління та населенням, та про адміністративні, соціальні і фінансові положення», який доповнено Законом № 2000-321 від 12 квітня 2000 року «Про права громадян у їх відношеннях з адміністрацією». Виконання цих законів покладено на незалежну Комісію по доступу до адміністративних документів (далі - Комісія) [14; 15].

Метою створення цієї Комісії є посилення прозорості діяльності публічної влади. Склад Комісії із 11 різних за своїм статусом осіб є гарантією їі незалежності. До неї входять три представники магістратури, три представники виборних посад, університетський професор і чотири представники галузевих спеціалістів. Кожен член комісії має помічника. Термін призначення помічника - три роки. Головуючий у Комісії державний радник, який присутній при прийнятті рішення. До Комісії звертається громадянин у тому випадку, якщо компетентний орган протягом місяця не виконає його запит щодо ознайомлення з відповідним документом, який викликає в нього зацікавленість, і не дає вмотивовану відмову. Комісія має розглянути причину відмови і протягом місяця дати заявнику відповідь. Контрольна роль Комісії полягає у виявленні недоліків у роботі адміністрації і формуванні рекомендацій по їх усуненню [14; 15$]$.

Звичайно, існують межі доступу до інформації, і вони зафіксовані у статті 311-5 Кодексу про відносини між адміністрацією і населенням. Відповідно до статті 311-6 цього Кодексу тільки зацікавлена особа може ознайомитися і одержати адміністративнідокументи:1)якіможутьнанестишкодузахистуособистогожиття, лікарській, комерційній і промисловій таємниці; 2) які містять оцінку або судження профізичну особу, яка дозволяє ії ідентифікувати; 3) які презентують поведінку особи, і в разі, коли оприлюднення відомостей про цю поведінку може нанести шкоду цій особі.

Комісія покликана для виконання трьох основних завдань: дає висновок про можливість або неможливість видачі певного документа і наділена при цьому великими слідчими повноваженнями. Звернення в Комісію є обов'язковим перед зверненням із позовом в органи адміністративної юстиції. Контрольна функція Комісії полягає у виявленні недоліків у роботі адміністрації і виробленні рекомендацій 3 ï усунення $[14 ; 15 ; 16]$. Таким чином, право кожного громадянина бути обізнаним в урядових справах, право отримувати рішення, які стосуються діяльності громади є основним принципом місцевої демократії. Влада повинна забезпечити простий спосіб доступу громадян до правових норм, які вона створює. Отже, право на інформацію про діяльність адміністративних органів, доступ до неї є умовою контролю над публічною владою. 
Франція пильно слідкує за вдосконаленням рівня систематизації законодавства у сфері відносин між громадянами і державною владою. Про це свідчить прийняття у 2016 році Кодексу відносин між адміністрацією та населенням. Принцип транспарентності публічного контролю запроваджує ідею відкритого для населення уряду, електронної адміністрації. Під електронною адміністрацією розуміють модель державного управління, яка заснована на використанні сучасних інформаційних та комунікаційних технологій з метою підвищення ефективності та прозорості влади, а також встановлення суспільного контролю над нею [16].

При цьому французький уряд також вжив заходів щодо створення цифрового публічного простору. Насамперед слід згадати запровадження програми PAGSI: «Програма урядової діяльності за інформаційне суспільство», яка була заявлена в 1997 році Прем'єр-міністром і спрямовувалася на поширення публічних парламентських інтернет-сайтів та зразків адміністративних документів [17].

12 квітня 2000 року був прийнятий Закон № 2000-321 «Про права громадян у їх відносинах із адміністрацією», який покладає на всі державні установи певні обов'язки щодо споживачів їх послуг [15]. На виконання наведеного Закону у Франції розроблено та введено в дію численні урядові програми, які покликані налагодити роботу у сфері електронних послуг. Зокрема, мою увагу привернула Програма під назвою «Біла книга: Електронна адміністрація і захист персональних даних», яка підготовлена Міністерством публічної служби в лютому 2002 року та була спрямована на посилення технічних та юридичних гарантій захисту персональних даних [18].

Крім того, у квітні 2004 року Прем'єр-міністром була започаткована урядова програма електронної адміністрації на 2004-2007 роки, спрямована на форсування розповсюдження інформаційних та комунікаційних технологій в адміністрації для того, щоб задовольнити очікування споживачів послуг і покращити ефективність публічних послуг [19].

Порівнюючи впровадження електронних послуг у Французькій Республіці, спрямованих на вдосконалення публічного контролю, необхідно зауважити, що процес побудови цифрового виміру державної адміністрації для спрощення доступу до неї громадян в Україні вже розпочато. Так, у лютому 2020 року Президент В. Зеленський, Прем’єр-міністр О. Гончарук та Міністерство цифрової трансформації презентували мобільний застосунок «Дія». Вже зараз у додатку працюють е-посвідчення водія та свідоцтво для реєстрації (техпаспорт) для автомобіля. О. Гончарук додав, що метою Уряду є протягом трьох років оцифрувати всі державні послуги, а 50 основних послуг - вже у 2020 році [20].

Отже, наведене свідчить про те, що процес введення електронних засобів в управлінських структурах, який нині відбувається в Україні, у Франції пройшов ще в 90 -х роках минулого століття. Саме тому буде доцільним звернути увагу на досвід «спроб і помилок» у сфері забезпечення роботи електронної адміністрації цієї країни.

Вважаю, що Україна рухається до створення цифрового суспільства, оскільки більшість країн Європейської спільноти вже подолали цей рубіж, суттєво підвищивши якість функціонування свого державного апарату. Електронна адміністра- 
ція є передумовою якісно нового рівня доступу населення до публічних даних та ефективного контролю з їх боку за діяльністю держави. Публічний контроль тісно пов'язаний із державною владою. Інститути публічної влади повинні діяти суворо в рамках закону. Публічний контроль іноді діє стихійно та емоційно, часто залежно від дій держави, які викликають суспільний резонанс.

Це відбувається тоді, коли населення не досить поінформоване про мету і засоби діяльності влади. Українські парламентарі намагалися унормувати публічний контроль. Однак спроба прийняти Закон України «Про публічний контроль» зазнала невдачічерезневизначеністьоб'єктутакогоконтролю,суб'єктів,якійогоздійснюють, процедуру проведення та наслідки такого контролю. Зокрема, проєкт відповідного закону від 6 липня 2015 року № 2297 а був запропонований для розгляду в Верховній Раді України без врахування європейської демократичної практики, яка грунтується на ідеї дорадчої демократії: врахуванні думки громадян у процесі прийняття владних рішень, що вважається однією із фундаментальних засад демократії [21].

Про актуальність поглиблення цифрового суспільства та укорінення його в найрізноманітніших сферах діяльності держави свідчить підписана під час зустрічі країн «Великої Вісімки» 18 червня 2013 року Хартія відкритості публічних даних [22]. Так, за даними моніторингу виконання державними органами законодавства щодо відкритих даних станом на 3 квітня 2020 року держоргани оприлюднили лише половину наборів даних, передбачених законодавством (53\%).

Одним із найбільш цінних оприлюднених датасетів є розклад судових засідань (розпорядник - Державна судова адміністрація). Завдяки OpenDataBot сторони в судових справах зможуть отримувати сповіщення, коли відбудуться їх засідання. Держпродспоживслужба опублікувала низку датасетів, пов' язаних із безпекою продуктів харчування, зокрема Державний реєстр потужностей операторів ринку, Реєстр висновків державної санепідекспертизи, Реєстр ветеринарних препаратів та інші.

Державне агентство лісових ресурсів України відкрило перелік сертифікатів про походження лісоматеріалів і пиломатеріалів, а Національне агентство $з$ питань запобігання корупції - Звіти політичних партій про майно, доходи, витрати і зобов'язання фінансового характеру. Жодного з окремо визначених у Постанові наборів не оприлюднили Міністерство охорони здоров'я України, Міністерство у справах ветеранів, тимчасово окупованих територій та внутрішньо переміщених осіб України, Національне антикорупційне бюро України, Вища рада правосуддя, Український гідрометеорологічний центр, Державна служба України з питань праці, Державна регуляторна служба України, Державне агентство України з питань кіно, НАК «Нафтогаз України», ДП «Український державний центр радіочастот» [23]. Зміст проаналізованих вище даних щодо стану реалізації державної політики у сфері впровадження цифрової «транспарентності» в практику роботи українських державних інституцій говорить про незначний прогрес. На мою думку, наведене стало можливим через відсутність системного контролю за станом опублікування відкритих даних.

Наведена статистика свідчить і про те, що рух у напрямі забезпечення безперешкодного доступу до відкритих даних про діяльність органів державної влади відбувається дуже повільно. У зв'язку з цим українському законодавцю слід звер- 
нути увагу на досвід роботи французьких парламентарів у сфері встановлення правил публічного контролю. Зокрема, запозичити курс на чітку регламентацію процедури взаємовпливу державної влади і громадськості, а також впровадження принципів прозорості та гласності в діяльність державного апарату з урахуванням елементів захисту як державної таємниці, так і персональних даних всіх учасників комунікативного діалогу.

Висновки. У демократичному суспільстві публічний контроль над державною владою з боку громадськості насамперед є гарантією дотримання прав та свобод людини і громадянина. Очевидним є вплив громадянського суспільства на законодавчу ініціативу державних структур, який можливий при активному якісному впровадженні публічного контролю. Таким чином, публічний контроль запобігає порушенню існуючих правових норм з боку органів влади та прийняттю посадовцями передчасних, упереджених, необгрунтованих рішень, вчиненню дій, які мають наслідком створення неякісного законодавства.

Активність публічного контролю над державною владою базується на таких критеріях, як відповідність мети і змісту діяльності державної влади інтересам більшості населення та політичної і соціальної свідомості соціуму, який спостерігає за діяльністю органів державної влади. Отже, публічний контроль можна охарактеризувати як вияв власної волі громадян щодо нагляду за діями інститутів державної влади. На мою думку, основою для здійснення ефективного публічного контролю $€$ налагоджена система доступу громадськості до всіх, які не є державною таємницею, аспектів діяльності держави, адже виміром соціальної ефективності влади є ступінь суспільної підтримки та довіри до її діяльності, рівень соціального схвалення та готовності населення безпосередньо допомагати владі, тобто співпрацювати з нею.

Можна зазначити, що для вдосконалення публічного контролю в Україні насамперед необхідно забезпечити прозорість діяльності органів державної влади та відкритий доступ до публічної інформації, яка стосується органів державної влади всіх рівнів. У цьому аспекті надзвичайно інформативним та практично застосовним щодо створення сприятливих умов для реалізації публічного контролю в Україні є досвід Франції.

\section{Jimepamypa}

1. Хук М. ван. Право как коммуникация. СПб. : ИД С. Петерб. гос. ун-та. 000 «Университетский издательский консорціум». 2012.288 с.

2. Лукойдес Л.Г. Справедливое судебное разбирательство (комментарий к п. 1 ст. 6 Европейской конвенции о защите прав человека и основных свобод) / Л.Г. Лукайдес // Рос. юстиция. 2004. № 2. C. $8-20$.

3. М. де Сальвиа. Прецеденты Европейского суда по правам человека. Руководящие принципы судебной практики, относящейся к Европейской конвенции о защите прав человека и основных свобод. Судебная практика с 1960 по 2002 г. СПб. : Юрид. центр Пресс, 2004. 1072 с.

4. Рахуа В.К. Общественно-исторические типы публичной власти / В.К. Рахуа. М., 2007. 403 с.

5. Давид Р., Жоффре-Спиноза К. Основные правовые системы современности / Р. Давид, К. Жоффре-Спинози. М., 1999. 611 с.

6. Ратичери Н. Правовая система и критерии публичности власти в гражданском обществе / Н. Ратичери // Правоведение. 2005. № 4. С. 31-55.

7. Проблеми теорії права і конституціоналізму у працях М.В. Цвіка /упоряд.: О.В. Петришин, С.В. Шевчук, О.Р. Дашковська та інші, відп. за вип. О.В. Петришин. Х. : Право, 2010. 272 с. 
8. Дюверже М. Политические партии / Пер. с фр. М. : Академический проект (Серия«Концепции»), 2000. $538 \mathrm{c.}$

9. Денисюк С.Ф. Громадський контроль як гарантія законності в адміністративній діяльності правоохоронних органів в Україні : монографія / С.Ф. Денисюк. Х. : ТД «Золота миля», 2010. 368 с.

10. Буханевич А. Публічний контроль у контексті сучасних дослідницьких підходів / А. Буханевич // Вісник Національної академії державного управління при Президентові України. 2009. № 1. C. 25-32. URL: http://nbuv.gov.ua/UJRN/Vnadu_2009_1_5. (дата звернення: 04.04.2020).

11. Транспарентність влади в контексті європейської інтеграції України: конспект лекції до короткотермінового семінару в системі підвищення кваліфікації кадрів / уклад: Е.А. Афонін, О.В. Суший. К. : НАДУ, 2010. 48 c.

12. Hood C., Heald D. eds Transparency: the key to better governance? 2006 (reprinted 2011), Proceedings of the British Academy (135). Oxford University Press Oxford, UK. 231 p.

13. D claration des droits de l'Homme et du citoyen de 1789. URL: http://www.textes.justice.gouv.fr/ textes-fondamentaux-10086/droits-de-lhomme-et-libertes-fondamentales-10087/declaration-des-droitsde-lhomme-et-du-citoyen-de-1789-10116.html (дата звернення: 24.03.2020).

14. Loi 78-753 du 17 juillet 1978 portant diverses mesures d'am lioration des relations entre l'administration et le public et diverses dispositions d'ordre administratif, social et fiscal. URL: https://www.legifrance.gouv.fr/affichTexte.do?cidTexte=JORFTEXT000000339241\&dateTexte= 20200322 (дата звернення: 24.03.2020).

15. Loi n 2000-321 du 12 avril 2000 relative aux droits des citoyens dans leurs relations avec les administrations. URL: https://www.legifrance.gouv.fr/affichTexte.do?cidTexte=JORFTEXT00000021 $5117 \&$ dateTexte=20200322 (дата звернення: 24.03.2020).

16. Code des relations entre le public et l'administration. URL: https://www.legifrance.gouv.fr/ affichCode.do?cidTexte=LEGITEXT000031366350 (дата звернення: 24.03.2020).

17. Programme d'action gouvernemental - Preparer l'entree de la France dans la societe de l'information, adopte par le Comite interministeriel pour la societe de l'information du 16 janvier 1998. URL: https://vecam.org/archives/article143.html (дата звернення: 24.03.2020).

18. Programme d'action gouvernemental - Administration électronique et protection des données personnelles, Livre Blanc, adopte par le Comite interministeriel pour la societe de l'information du 26 février 2002. URL: https://www.leslivresblancs.fr/livre/informatique-et-logiciels/cybersecurite/administration-electronique-et-protection-des-donnees (дата звернення: 04.04.2020).

19. Programme d'action gouvernemental - L'administration lectronique 2004/2007-ADELE du 7 janvier 2004. URL: https://www.senat.fr/rap/r03-422/r03-422_mono.html (дата звернення: 04.04.2020).

20. Президент, Прем’єр-міністр, Мінцифри презентували мобільний застосунок «Дія». Урядовий портал. URL: https://www.kmu.gov.ua/news/prezident-premyer-ministr-mincifra-prezentuvalimobilnij-zastosunok-diya (дата звернення: 04.04.2020).

21. Проєкт Закону України «Про публічний контроль» № 2297а від 06.07.2015. Офіційний вебпортал Верховної Ради України. URL: http://w1.c1.rada.gov.ua/pls/zweb2/webproc4_1?pf3511=55907 (дата звернення: 04.04.2020).

22. G8 Open Data Charter. URL: https://www.gov.uk/government/publications/open-data-charter/ g8-open-data-charter-and-technical-annex (дата звернення: 04.04.2020).

23. Свіжі дані моніторингу виконання державними органами законодавства щодо відкритих даних. Єдиний державний вебпортал відкритих даних. URL: https://data.gov.ua/blog/svizhi-danimonitorynhu-vykonannia-derzhavnymy-orhanamy-postanovy-835 (дата звернення: 04.04.2020). 


\begin{abstract}
Анотація
Крегул Я. М. Публічний контроль в Україні та Франції: порівняльно- правове дослідження. Стаття.

Статтю присвячено дослідженню явища публічного контролю, визначенню його ролі в якості основного елементу взаємодії держави та суспільства, що створює підгрунтя для соціального спрямування політики держави. Так, серед факторів, які зумовлюють розвиток правової бази держави, автором зауважено на доцільності впровадження в процес нормотворення не лише органів влади, які наділені правотворчими функціями за Конституцією держави, а і тих неформальних соціальних структур, які, можливо, не будуть відігравати визначальної ролі в цьому процесі, однак зможуть надати аргументи «за» або «проти» прийняття певних нормативно-правових актів.

У дослідженні з'ясовано, що державна влада вимагає контролю з боку громадськості, оскільки фактично саме остання надала їй повноваження для створення правового поля. В свою чергу публічний контроль, з точки зору автора, необхідний саме для досягнення ефективної комунікації між владою та громадянським суспільством.

В рамках запропонованого дослідження проаналізовано вплив різноманітних факторів на якість здійснення публічного контролю. Зокрема, зазначено про значну роль інформаційної політики держави та використання сучасних цифрових технологій у забезпеченні доступу громадськості до публічних даних про діяльність державних інституцій.

Автор підкреслює, що право кожного громадянина бути обізнаним в урядових справах та отримувати рішення, які стосуються діяльності громади, є основним принципом демократії. Влада повинна забезпечити простий спосіб доступу громадян до даних про свою роботу та правових норм, які вона створює. Саме тому дослідник доходить висновку про те, що рівень «прозорості» інформації про діяльність адміністративних органів і доступ до неї є умовою ефективного публічного контролю.

Автором виявлені і недоліки практичного втілення принципу «транспарентності» в діяльності державної влади в Україні та запропоновано шляхи його удосконалення, спираючись на досвід Французької Республіки, яка досягла суттєвих успіхів у сфері нормативно-правового та технічного закріплення взаємовідносин між громадянами і державною владою.

Ключові слова: взаємодія громадськості та державної влади, відкриті дані, цифрова політика, транспарентність, нормотворення.
\end{abstract}

\title{
Summary
}

Krehul I. M. Public control in Ukraine and France: a comparative legal study. - Article.

This article is devoted to the study of public control, its role as the main element of interaction between the state and society is defined. It creates the basis for the social orientation of public policy. Among the factors that determine the development of the legal framework of the state, the author noted the feasibility of introducing into the process of rule-making not only authorities that are endowed with law-making functions under the Constitution of the state, but as well as those informal social structures that may not play a decisive role in this process, but will be able to provide arguments "for" or "against" the adoption of certain regulations.

The study has found that public authorities require public scrutiny, because in fact the society has given it the power to create the legal field. Conversely public control, in the author's view, is necessary in order to achieve effective communication between the government and civil society.

In addition to the above it should be mentioned that during this study was also analyzed the impact of various agencies on public oversight powers. In particular, was indicated the direct dependence of its quality on the state's information policy and the use of modern digital technologies in ensuring public access to public data on the activities of state institutions. The author emphasizes that the right of every citizen to be aware of government affairs and to receive decisions concerning the activities of the community is a fundamental principle of democracy.

In turn, the government should provide an easy way for citizens to access data about their work and the legal norms it creates. Therefore the researcher concludes that the level of "transparency" of information about the activities of administrative bodies and access to it is a condition for effective public control.

The author also points out that there are shortcomings in the practical implementation of the principle of "transparency" in the activities of state authorities in Ukraine and offers way of it's improvement, based on the experience of the French Republic, which has made significant progress in establishing a legal and technical relationship between the citizens and the State.

Key words: interacion of the public society and government, open data, digital policy, transparency, criation of legal rules. 